\title{
Does beer, wine or liquor consumption correlate with the risk of renal cell carcinoma? A dose-response meta-analysis of prospective cohort studies
}

\author{
Xin $X u^{1}$, Yi Zhu ${ }^{1}$, Xiangyi Zheng ${ }^{1}$, Liping $X^{1}{ }^{1}$ \\ ${ }^{1}$ Department of Urology, The First Affiliated Hospital, School of Medicine, Zhejiang University, Hangzhou, China \\ Correspondence to: \\ Liping Xie, e-mail: xielp@zju.edu.cn \\ Keywords: alcohol, renal cell carcinoma, epidemiology, risk factor, meta- \\ analysisReceived: February 24, $2015 \quad$ Accepted: April 15, $2015 \quad$ Published: April 29, 2015
}

\section{ABSTRACT}

Despite plenty of evidence supports an inverse association between alcohol drinking and risk of renal cell carcinoma (RCC), sex-specific and beverage-specific dose-response relationships have not been well established. We examined this association by performing a systematic review and meta-analysis of prospective studies. Studies were identified by comprehensively searching PubMed and EMBASE databases through February 21, 2015. Categorical and dose-response meta-analyses were conducted to identify the effects of alcohol on RCC. A total of eight publications (including seven cohort studies and one pooled analysis of 12 cohort studies) were eligible for this meta-analysis. Dose-response analysis showed that each $\mathbf{5} \mathbf{g} / \mathrm{day}$ increment of alcohol intake corresponded to a $5 \%$ decrease in risk of RCC for males and $\mathbf{9 \%}$ for females. Alcohol intakes from wine, beer, and liquor were each associated with a reduced risk of RCC. When these associations were examined separately by gender, statistically significant inverse associations were restricted to alcohol from wine among females $(R R=0.82,95 \% \mathrm{CI} 0.73-0.91)$ and to alcohol from beer and from liquor among males $(R R=0.87,95 \%$ CI $0.83-0.91$ and $R R=0.95,95 \%$ CI $0.92-0.99$, respectively). In conclusion, there exist gender-specific and beveragespecific differences in the association between alcohol intake and RCC risk.

\section{INTRODUCTION}

Kidney cancer is one of the ten most common types of cancer worldwide, with over 271,000 newly diagnosed cases and over 116,000 deaths in 2008 [1]. The most common form, renal cell carcinoma (RCC) of the renal parenchyma, accounts for over $85 \%$ of all kidney cancers [2, 3]. RCC incidence rates vary substantially over the world. Rates are generally high in more developed regions (e.g., Europe and North America) and low in less developed areas (e.g., Asia and South America) [2]. RCC occurs twice as often in males as in females [4]. Although the reason for the higher incidence in developed countries and in males is not very clear [5], the nonhomogeneity of RCC incidence rates implies the existence of modifiable risk factors. On the other hand, RCC incidence is rising by approximately 2 to $3 \%$ per year $[1,6]$, which is due in large part to the increasing use of diagnostic imaging (ultrasound, magnetic resonance imaging, and computerized tomography scan)
[7]. However, both advanced stage disease and the mortality rate for renal cancers have also been increasing, suggesting that risk factors have played some role in this upward trend $[3,6]$. Based on the current evidence, cigarette smoking, obesity and hypertension are the most well established risk factors for RCC $[2,3]$.

Recent epidemiological studies have suggested that moderate alcohol drinking may be associated with a reduced risk of RCC $[2,3,8]$. Two well-done systematic reviews conducted in 2012 also supported this idea $[9,10]$. Nevertheless, the results of recently published prospective cohort studies remain inconsistent or conflicting [11-13]. Karami et al. [12] showed that increasing alcohol consumption was associated with reduced RCC risk. Macleod et al. [11] found the trend, but they just did not reach the statistical significance. Washio et al. [13] reported that alcohol drinking was not related to the kidney cancer mortality. Moreover, sex-specific and beverage-specific (beer, wine or liquor) relationship between alcohol intake and RCC risk has not yet 
been established. We are wondering whether there is a gender difference in this association and whether different types of alcoholic beverages affect RCC risk differently.

We therefore conducted a dose-response metaanalysis on alcohol consumption and RCC risk by summarizing the results of all relevant prospective studies. Our aim was to update evidence on the association between them, and to quantify the sex-specific and beverage-specific dose-response relationships.

\section{RESULTS}

\section{Literature search and study characteristics}

We identified eight publications of alcohol drinking and RCC risk [11, 12, 14-19] (Figure 1), including seven independent cohort studies and one pooled analysis of 12 cohort studies. A total of 5,503 RCC cases were eligible for this systematic review. Four studies were conducted in United States [11, 12, 17, 19], one in Japan [16], one in Korea [18], one in United Kingdom [15], and one in multiple countries [14]. Studies were published between 2007 and
2014. The studies [11, 12, 14-19] that provided at least 3 quantitative categories of alcohol drinking were included in dose-response meta-analysis. Most studies adjusted for age [11, 14-19], race [11, 12, 17, 19], smoking [11, 12, 14, 15, 17-19], body mass index (BMI) [11, 12, 14, 15, 18, 19], hypertension $[11,12,14,17-19]$, and physical activity [15, 17-19]. Six studies [11, 12, 14, 15, 17, 19] used incidence of renal cell carcinoma as outcome, and two [16, 18] used kidney cancer mortality. The points of study quality assessed by Newcastle-Ottawa quality assessment scale ranged from 6 to 9 (with a mean of 7.5). Detailed characteristics of the included studies are presented in Table 1.

\section{Categorical meta-analysis}

Supplementary Figure S1 shows the study-specific and pooled RRs and 95\% CIs of RCC for any, light, moderate, and heavy drinking. When compared with non/occasional drinking, the pooled RRs were 0.86 (95\% CI 0.76-0.96; $\left.I^{2}=60.1 \%\right)$ for any, $0.92\left(95 \%\right.$ CI $\left.0.83-1.01 ; I^{2}=45.2 \%\right)$ for light, 0.75 for $\left(95 \%\right.$ CI $\left.0.66-0.86 ; I^{2}=45.1 \%\right)$ for moderate, and $1.08\left(95 \%\right.$ CI $\left.0.42-2.75 ; I^{2}=74.8 \%\right)$ for heavy drinking.

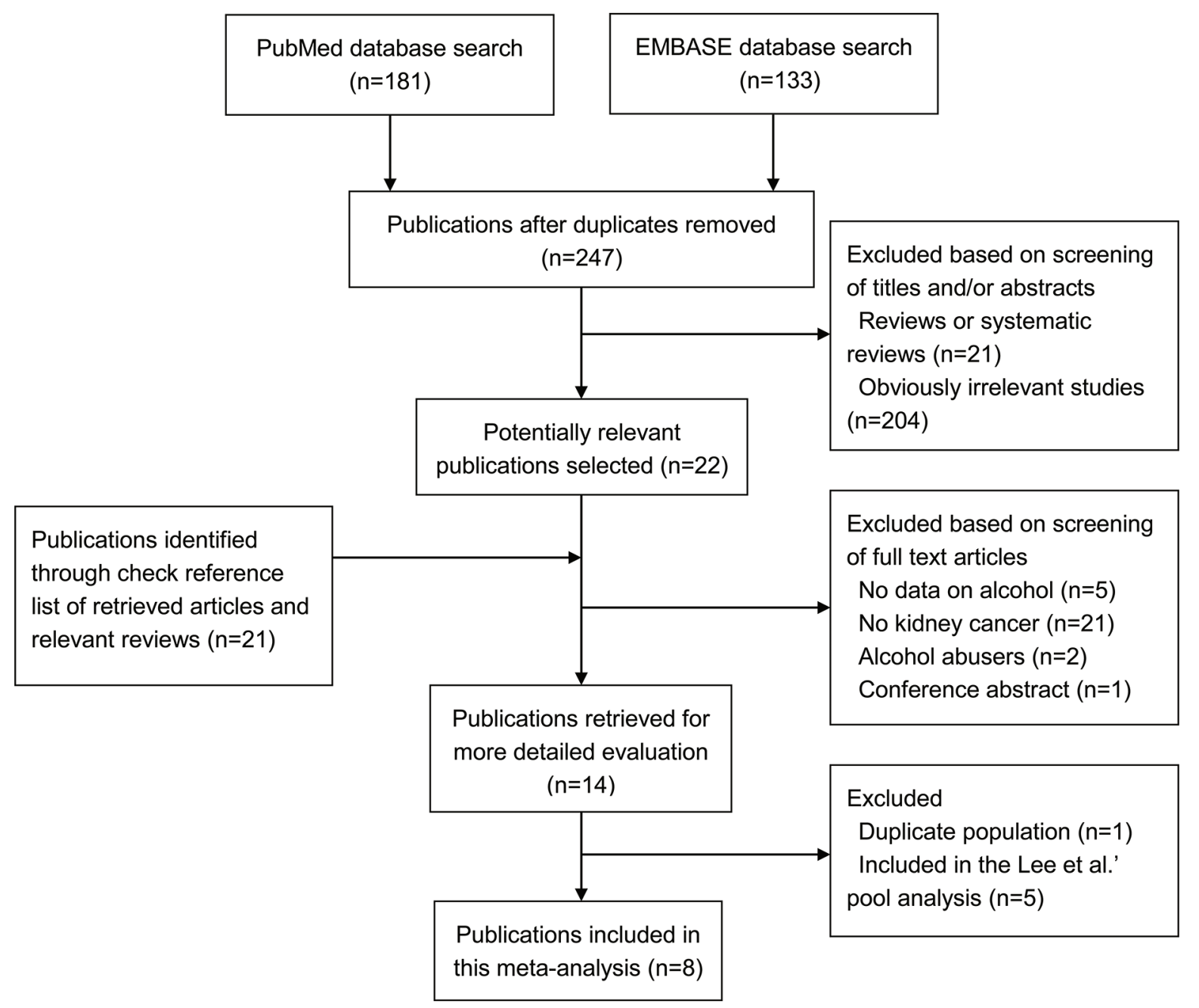

Figure 1: Flowchart of selection of studies for inclusion in this meta-analysis. 
Table 1: Main characteristics of studies included in this meta-analysis

\begin{tabular}{|c|c|c|c|c|c|c|c|c|}
\hline $\begin{array}{l}\text { First author, } \\
\text { year, country }\end{array}$ & Gender (age) & Alcohol assessment & Outcome & $\begin{array}{l}\text { No. of } \\
\text { cases }\end{array}$ & No. of cohort & $\begin{array}{l}\text { Duration } \\
\text { of follow- } \\
\text { up }\end{array}$ & $\begin{array}{l}\text { Quality } \\
\text { score }\end{array}$ & $\begin{array}{l}\text { Adjustment } \\
\text { variables }\end{array}$ \\
\hline $\begin{array}{l}\text { Karami et al., } \\
\text { 2014, USA }\end{array}$ & $\begin{array}{l}\mathrm{MF}(55-74, \\
\text { range) }\end{array}$ & Questionnaire & $\begin{array}{l}\text { Incidence } \\
\text { of renal cell } \\
\text { carcinoma }\end{array}$ & 408 & $107,998(\mathrm{PR})$ & $11.4 \mathrm{y}$ & 7 & $\begin{array}{l}\text { Sex, race, } \\
\text { hypertension, } \\
\text { BMI, smoking } \\
\text { status, and study } \\
\text { center }\end{array}$ \\
\hline $\begin{array}{l}\text { Macleod et al., } \\
\text { 2013, USA }\end{array}$ & $\begin{array}{l}\mathrm{MF}(50-76, \\
\text { range })\end{array}$ & FFQ & $\begin{array}{l}\text { Incidence } \\
\text { of renal cell } \\
\text { carcinoma }\end{array}$ & 249 & 77,260 (PR) & $8 \mathrm{y}$ & 8 & $\begin{array}{l}\text { Age, gender, } \\
\text { race, BMI, } \\
\text { smoking, } \\
\text { fruit intake, } \\
\text { vegetable intake, } \\
\text { hypertension, } \\
\text { diabetes, kidney } \\
\text { disease, and viral } \\
\text { hepatitis }\end{array}$ \\
\hline $\begin{array}{l}\text { Lew et al., } \\
\text { 2011, USA }\end{array}$ & $\begin{array}{l}\mathrm{M}(50-71, \\
\text { range) }\end{array}$ & FFQ & $\begin{array}{l}\text { Incidence } \\
\text { of renal cell } \\
\text { cancer }\end{array}$ & 1,348 & 293,466 (PR) & $8 \mathrm{y}$ & 8 & $\begin{array}{l}\text { Age, race, } \\
\text { education, } \\
\text { marital status, } \\
\text { BMI, smoking, } \\
\text { physical activity, } \\
\text { hypertension, } \\
\text { and intakes of } \\
\text { protein and total } \\
\text { energy excluding } \\
\text { calories from } \\
\text { alcohol. }\end{array}$ \\
\hline $\begin{array}{l}\text { Lew et al., } \\
\text { 2011, USA }\end{array}$ & $\begin{array}{l}\mathrm{F}(50-71, \\
\text { range) }\end{array}$ & FFQ & $\begin{array}{l}\text { Incidence } \\
\text { of renal cell } \\
\text { cancer }\end{array}$ & 466 & $198,721(\mathrm{PR})$ & $8 \mathrm{y}$ & 8 & $\begin{array}{l}\text { Age, race, } \\
\text { education, } \\
\text { marital status, } \\
\text { BMI, smoking, } \\
\text { physical activity, } \\
\text { hypertension, and } \\
\text { intakes of protein } \\
\text { and total energy } \\
\text { excluding calories } \\
\text { from alcohol. }\end{array}$ \\
\hline $\begin{array}{l}\text { Kim, et al., } \\
\text { 2010, Korea }\end{array}$ & $\begin{array}{l}\mathrm{M}(40-69, \\
\text { range) }\end{array}$ & Health examination & $\begin{array}{l}\text { Kidney } \\
\text { cancer } \\
\text { mortality }\end{array}$ & 74 & 919,199 (PR) & $5 y$ & 7 & $\begin{array}{l}\text { Age, residential, } \\
\text { smoking status, } \\
\geq 3 \text { times/week } \\
\text { regular exercise, } \\
\text { BMI, systolic } \\
\text { and diastolic } \\
\text { blood pressure, } \\
\text { and fasting blood } \\
\text { sugar }\end{array}$ \\
\hline $\begin{array}{l}\text { Allen et al., } \\
\text { 2009, UK }\end{array}$ & $\mathrm{F}(55$, average $)$ & Questionnaire & $\begin{array}{l}\text { Incidence } \\
\text { of renal cell } \\
\text { carcinoma }\end{array}$ & 1,141 & $\begin{array}{c}1,280,296 \\
(\mathrm{PR})\end{array}$ & $7.2 \mathrm{y}$ & 7 & $\begin{array}{l}\text { Age, region } \\
\text { of residence, } \\
\text { socioeconomic } \\
\text { status, BMI, } \\
\text { smoking, } \\
\text { physical activity, } \\
\text { use of oral } \\
\text { contraceptives, } \\
\text { and hormone } \\
\text { replacement } \\
\text { therapy }\end{array}$ \\
\hline
\end{tabular}

(Continued) 


\begin{tabular}{|c|c|c|c|c|c|c|c|c|}
\hline $\begin{array}{l}\text { First author, } \\
\text { year, country }\end{array}$ & Gender (age) & Alcohol assessment & Outcome & $\begin{array}{l}\text { No. of } \\
\text { cases }\end{array}$ & No. of cohort & $\begin{array}{c}\text { Duration } \\
\text { of follow- } \\
\text { up }\end{array}$ & $\begin{array}{l}\text { Quality } \\
\text { score }\end{array}$ & $\begin{array}{l}\text { Adjustment } \\
\text { variables }\end{array}$ \\
\hline $\begin{array}{l}\text { Setiawan } \\
\text { et al., 2007, } \\
\text { USA }\end{array}$ & $\mathrm{M}(59.3$, mean $)$ & Questionnaire & $\begin{array}{l}\text { Incidence } \\
\text { of renal cell } \\
\text { cancer }\end{array}$ & 220 & 75,162 (PR) & $8.3 \mathrm{y}$ & 8 & $\begin{array}{l}\text { Age, ethnicity, } \\
\text { smoking, } \\
\text { hypertension, } \\
\text { and physical } \\
\text { activity }\end{array}$ \\
\hline $\begin{array}{l}\text { Setiawan } \\
\text { et al., 2007, } \\
\text { USA }\end{array}$ & $\mathrm{F}(58.8$, mean $)$ & Questionnaire & $\begin{array}{l}\text { Incidence } \\
\text { of renal cell } \\
\text { cancer }\end{array}$ & 127 & 85,964 (PR) & $8.3 \mathrm{y}$ & 8 & $\begin{array}{l}\text { Age, ethnicity, } \\
\text { smoking, } \\
\text { hypertension, } \\
\text { andphysical } \\
\text { activity }\end{array}$ \\
\hline $\begin{array}{l}\text { Ozasa et al., } \\
\text { 2007, Japan }\end{array}$ & M & NA & $\begin{array}{l}\text { Kidney } \\
\text { cancer } \\
\text { mortality } \\
\end{array}$ & 28 & 427,155 (PY) & NA & 6 & $\begin{array}{l}\text { Age and area of } \\
\text { study }\end{array}$ \\
\hline $\begin{array}{l}\text { Ozasa et al., } \\
\text { 2007, Japan }\end{array}$ & $\mathrm{F}$ & NA & $\begin{array}{l}\text { Kidney } \\
\text { cancer } \\
\text { mortality }\end{array}$ & 12 & 642,381(PY) & NA & 6 & $\begin{array}{l}\text { Age and area of } \\
\text { study }\end{array}$ \\
\hline $\begin{array}{l}\text { Lee et al., } \\
2007, \\
\text { International }\end{array}$ & $\begin{array}{l}\text { MF } \\
\text { (15-107,range) }\end{array}$ & FFQ & $\begin{array}{l}\text { Incidence } \\
\text { of renal cell } \\
\text { cancer }\end{array}$ & 1,430 & 760,044(PR) & $7-20 y$ & 9 & $\begin{array}{l}\text { Age, history of } \\
\text { hypertension, } \\
\text { BMI, pack-years } \\
\text { of smoking, } \\
\text { combination of } \\
\text { parity and age } \\
\text { at first birth, } \\
\text { and total energy } \\
\text { intake }\end{array}$ \\
\hline
\end{tabular}

BMI, body mass index; No., number; MF, male and female; F, female; M, male; y, years; FFQ, food frequency questionnaire; PR, person at risk; PY, person year; NA, not available

Table 2 gives the pooled RRs and 95\% CIs of RCC at different levels of alcohol drinking in strata of relevant factors. For any drinking, significant results were found in subgroups of females $(\mathrm{RR}=0.84,95 \%$ CI $0.75-0.94$; $\left.I^{2}=24.6 \%\right)$, USA $(\mathrm{RR}=0.87,95 \%$ CI $0.76-0.99$; $\left.I^{2}=51.3 \%\right)$, quality score $\geq$ mean $(\mathrm{RR}=0.89,95 \% \mathrm{CI}$ $\left.0.79-0.99 ; I^{2}=71.7 \%\right)$, Caucasian $(\mathrm{RR}=0.89,95 \% \mathrm{CI}$ $\left.0.81-0.97 ; I^{2}=44.0 \%\right)$, and incidence $(\mathrm{RR}=0.88,95 \%$ CI $0.81-0.95 ; I^{2}=34.7 \%$ ). For light drinking, results were not materially different in strata of area, ethnicity, and outcome, but not in other strata. For moderate drinking, results were basically consistent in strata of sex and major confounders adjusted, but not in other strata.

Supplementary Figure S2 presents the results of sensitivity analysis for any, light, and moderate drinking. The pooled RRs with $95 \%$ CIs ranged from 0.82 (95\% CI $0.74-0.92)$ to 0.88 (95\% CI $0.79-0.98)$ for any, from 0.88 ( $95 \%$ CI $0.82-0.95$ ) to 0.93 (95\% CI $0.84-1.02$ ) for light, and from 0.73 (95\% CI $0.63-0.84)$ to 0.77 (95\% CI 0.68-0.88) for moderate drinking, which indicated that the pooled estimates were robust and not influenced by a single study for any and moderate drinking, but not for light drinking. No significant publication bias was detected by Egger's test and Begg's test for any, light, and moderate drinking (All $P>0.5$ ).

\section{Dose-response meta-analysis}

The number of studies eligible for the dose-response analysis was eight [11, 12, 14-19], six [12, 14, 16-19], and five $[12,14,15,17,19]$ for overall population, males, and females, respectively. Accordingly, the pooled RRs of RCC for $5 \mathrm{~g} /$ day increment of alcohol drinking decreased by $6 \%(\mathrm{RR}=0.94,95 \% \mathrm{CI} 0.92-0.95), 5 \%(\mathrm{RR}=0.95,95 \%$ CI $0.93-0.97)$, and $9 \%(\mathrm{RR}=0.91,95 \%$ CI $0.88-0.94)$, respectively. Some evidence of a nonlinear relationship between alcohol and RCC risk was found for overall population ( $P=0.03$ for nonlinearity) and males $(P=0.05$ for nonlinearity). The downward trend was most obvious when alcohol intake increased up to about $12.5 \mathrm{~g}$ /day (Figure 2).

Three studies [12, 14, 19] were eligible for the beverage-specific dose-response analysis. Alcohol intakes from wine, beer, and liquor were each associated with a reduced risk of RCC among the overall population. The pooled RRs for a $5 \mathrm{~g} /$ day increase in alcohol intake were 0.94 (95\% CI $0.90-0.99), 0.89$ (95\% CI 0.85-0.93), and 0.96 (95\% CI $0.92-0.99)$, respectively (Figure 3 ). There was no evidence of nonlinearity. All $P$ values for nonlinear assessment were $>0.05$.

These beverage-specific associations were then examined separately by gender, and the statistically 
Table 2: Pooled and subgroup analyses stratified by sex, area, major confounders adjusted, quality score, ethnicity, and outcome

\begin{tabular}{|c|c|c|c|c|c|c|c|c|c|c|c|c|}
\hline & \multicolumn{4}{|c|}{ Any versus non/occasional } & \multicolumn{4}{|c|}{ Light versus non/occasional } & \multicolumn{4}{|c|}{$\begin{array}{c}\text { Moderate versus non/ } \\
\text { occasional }\end{array}$} \\
\hline & $N^{\mathrm{a}}$ & $\begin{array}{c}\text { RR } \\
(95 \% \\
\text { CI })\end{array}$ & $I^{2}(\%)$ & $P$ value ${ }^{b}$ & $N^{\mathrm{a}}$ & $\begin{array}{c}\text { RR } \\
(95 \% \\
\text { CI })\end{array}$ & $I^{2}(\%)$ & $\begin{array}{c}P \\
\text { value }^{b}\end{array}$ & $N^{\mathrm{a}}$ & $\begin{array}{c}\text { RR } \\
(95 \% \\
\text { CI })\end{array}$ & $I^{2}(\%)$ & $P$ value $^{\mathrm{b}}$ \\
\hline Overall & 8 & $\begin{array}{c}0.86 \\
(0.76- \\
0.96)\end{array}$ & 60.1 & 0.005 & 6 & $\begin{array}{c}0.92 \\
(0.83- \\
1.01)\end{array}$ & 45.2 & 0.078 & 8 & $\begin{array}{c}0.75 \\
(0.66- \\
0.86)\end{array}$ & 45.1 & 0.068 \\
\hline \multicolumn{13}{|l|}{$\operatorname{Sex}^{\mathrm{c}}$} \\
\hline Male & 6 & $\begin{array}{c}0.86 \\
(0.70- \\
1.06)\end{array}$ & 70.9 & 0.004 & 5 & $\begin{array}{c}0.99 \\
(0.85- \\
1.16)\end{array}$ & 43.2 & 0.134 & 6 & $\begin{array}{c}0.76 \\
(0.62- \\
0.92)\end{array}$ & 46.7 & 0.095 \\
\hline Female & 6 & $\begin{array}{c}0.84 \\
(0.75- \\
0.94)\end{array}$ & 24.6 & 0.249 & 5 & $\begin{array}{c}0.87 \\
(0.80- \\
0.95)\end{array}$ & 0.0 & 0.840 & 4 & $\begin{array}{c}0.72 \\
(0.62- \\
0.84)\end{array}$ & 6.7 & 0.360 \\
\hline \multicolumn{13}{|l|}{ Area $^{d}$} \\
\hline USA & 4 & $\begin{array}{c}0.87 \\
(0.76- \\
0.99)\end{array}$ & 51.3 & 0.086 & 3 & $\begin{array}{c}0.93 \\
(0.79- \\
1.09)\end{array}$ & 57.2 & 0.053 & 4 & $\begin{array}{c}0.75 \\
(0.63- \\
0.90)\end{array}$ & 46.9 & 0.110 \\
\hline Europe & 1 & $\begin{array}{c}0.86 \\
(0.75- \\
0.98)\end{array}$ & - & - & 1 & $\begin{array}{c}0.89 \\
(0.77- \\
1.02)\end{array}$ & - & - & 1 & $\begin{array}{c}0.78 \\
(0.66- \\
0.93)\end{array}$ & - & - \\
\hline Asia & 2 & $\begin{array}{l}1.91 \\
(0.35- \\
10.48)\end{array}$ & 84.6 & 0.001 & 1 & $\begin{array}{c}0.63 \\
(0.35- \\
1.13)\end{array}$ & - & - & 2 & $\begin{array}{c}1.07 \\
(0.18- \\
6.41)\end{array}$ & 84.3 & 0.012 \\
\hline \multicolumn{13}{|l|}{$\begin{array}{l}\text { Major } \\
\text { confounders } \\
\text { adjusted }^{\text {e }}\end{array}$} \\
\hline Yes & 4 & $\begin{array}{c}0.86 \\
(0.73- \\
1.02)\end{array}$ & 70.8 & 0.008 & 3 & $\begin{array}{c}0.95 \\
(0.80- \\
1.13)\end{array}$ & 68.9 & 0.022 & 4 & $\begin{array}{c}0.75 \\
(0.62- \\
0.90)\end{array}$ & 55.1 & 0.063 \\
\hline No & 4 & $\begin{array}{c}0.84 \\
(0.70- \\
1.02)\end{array}$ & 49.8 & 0.077 & 3 & $\begin{array}{c}0.87 \\
(0.78- \\
0.97)\end{array}$ & 0 & 0.914 & 4 & $\begin{array}{c}0.75 \\
(0.60- \\
0.94)\end{array}$ & 45.7 & 0.137 \\
\hline \multicolumn{13}{|l|}{ Quality score } \\
\hline$\geq$ Mean & 4 & $\begin{array}{c}0.89 \\
(0.79- \\
0.99)\end{array}$ & 71.7 & 0.007 & 3 & $\begin{array}{c}0.94 \\
(0.82- \\
1.08)\end{array}$ & 58.4 & 0.047 & 4 & $\begin{array}{c}0.76 \\
(0.66- \\
0.89)\end{array}$ & 44.6 & 0.124 \\
\hline$<$ Mean & 4 & $\begin{array}{c}0.84 \\
(0.61- \\
1.16)\end{array}$ & 47.2 & 0.092 & 3 & $\begin{array}{c}0.87 \\
(0.78- \\
0.98)\end{array}$ & 0 & 0.526 & 4 & $\begin{array}{c}0.74 \\
(0.54- \\
1.01)\end{array}$ & 58.1 & 0.067 \\
\hline \multicolumn{13}{|l|}{ Ethnicity $^{\mathrm{f}}$} \\
\hline Caucasian & 5 & $\begin{array}{c}0.89 \\
(0.81- \\
0.97)\end{array}$ & 44.0 & 0.112 & 4 & $\begin{array}{c}0.95 \\
(0.85- \\
1.06)\end{array}$ & 57.7 & 0.051 & 5 & $\begin{array}{c}0.77 \\
(0.68- \\
0.86)\end{array}$ & 35.5 & 0.170 \\
\hline
\end{tabular}

(Continued) 


\begin{tabular}{|c|c|c|c|c|c|c|c|c|c|c|c|c|}
\hline & \multicolumn{4}{|c|}{ Any versus non/occasional } & \multicolumn{4}{|c|}{ Light versus non/occasional } & \multicolumn{4}{|c|}{$\begin{array}{c}\text { Moderate versus non/ } \\
\text { occasional }\end{array}$} \\
\hline & $N^{\mathrm{a}}$ & $\begin{array}{c}\text { RR } \\
(95 \% \\
\text { CI) }\end{array}$ & $I^{2}(\%)$ & $P$ value $^{\mathrm{b}}$ & $N^{\mathrm{a}}$ & $\begin{array}{c}\text { RR } \\
(95 \% \\
\text { CI) }\end{array}$ & $I^{2}(\%)$ & $\begin{array}{c}P \\
\text { value }^{\mathrm{b}}\end{array}$ & $N^{\mathrm{a}}$ & $\begin{array}{c}\text { RR } \\
(95 \% \\
\text { CI) }\end{array}$ & $I^{2}(\%)$ & $P$ value $^{\mathrm{b}}$ \\
\hline Asian & 2 & $\begin{array}{c}1.91 \\
(0.35- \\
10.48)\end{array}$ & 84.6 & 0.001 & 1 & $\begin{array}{c}0.63 \\
(0.35- \\
1.13)\end{array}$ & - & - & 2 & $\begin{array}{c}1.07 \\
(0.18- \\
6.41)\end{array}$ & 84.3 & 0.012 \\
\hline \multicolumn{13}{|l|}{ Outcome } \\
\hline Incidence & 6 & $\begin{array}{c}0.88 \\
(0.81- \\
0.95) \\
\end{array}$ & 34.7 & 0.151 & 5 & $\begin{array}{r}0.93 \\
(0.84- \\
1.02) \\
\end{array}$ & 45.4 & 0.089 & 6 & $\begin{array}{c}0.76 \\
(0.69- \\
0.85) \\
\end{array}$ & 26.5 & 0.226 \\
\hline Mortality & 2 & $\begin{array}{c}1.91 \\
(0.35- \\
10.48)\end{array}$ & 84.6 & 0.001 & 1 & $\begin{array}{c}0.63 \\
(0.35- \\
1.13)\end{array}$ & - & - & 2 & $\begin{array}{c}1.07 \\
(0.18- \\
6.41)\end{array}$ & 84.3 & 0.012 \\
\hline
\end{tabular}

${ }^{a}$ The number of studies included.

${ }^{\mathrm{b}} P$ for heterogeneity in subgroups.

'Studies which reported or could calculate the sex-specific estimates were selected.

dStudy reported by Lee et al. containing multiple countries was not included in the subgroup analysis of area.

eStudies adjusted for age, smoking, body mass index, and hypertension.

fStudy reported by Setiawan et al. containing multiple ethnicities was not included in the subgroup analysis of ethnicity.
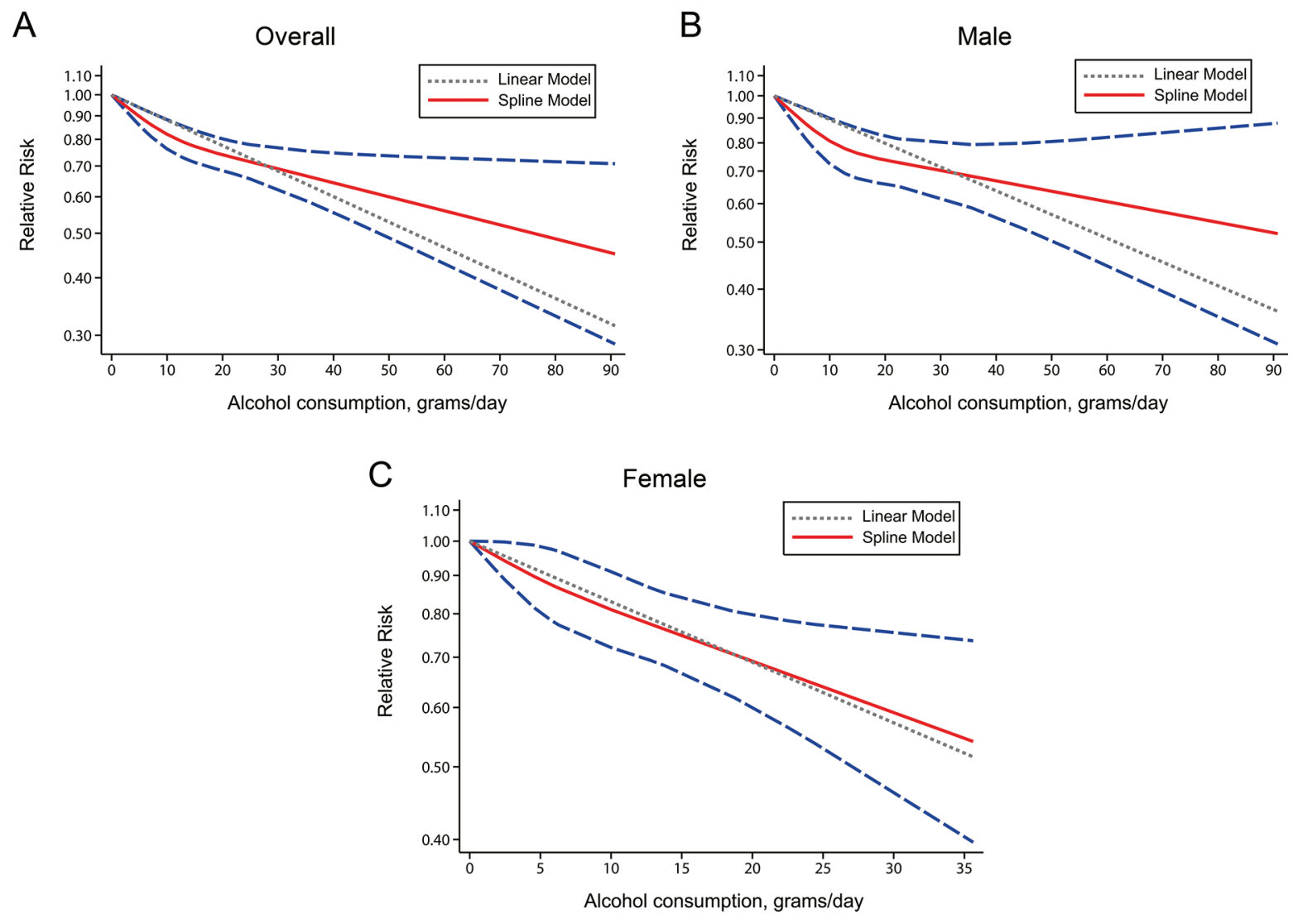

Figure 2: Relative risks (RRs) and the corresponding 95\% confidence intervals (CIs) for the dose-response relationship between alcohol drinking (grams per day) and renal cell carcinoma (RCC) risk among the overall population A. males B. and females $\mathbf{C}$. The solid line and the long dash line represent the estimated RRs and their 95\% CIs. Short dash line represents the linear relationship. 
A

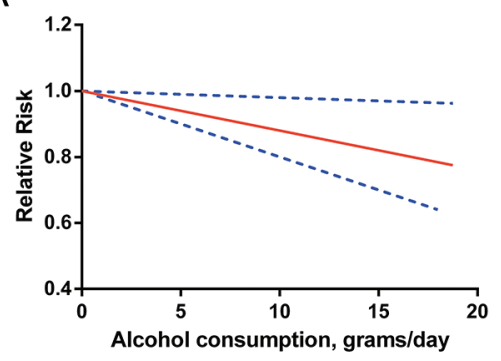

Wine
B

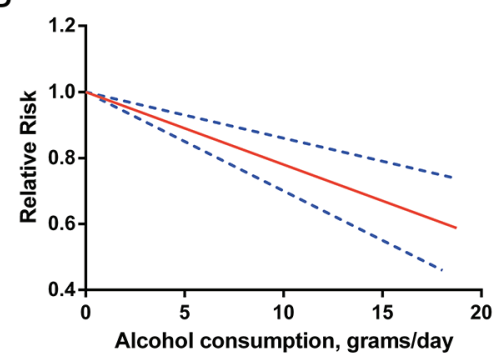

Beer
C

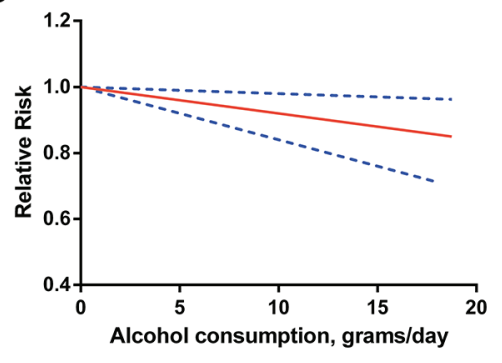

Liquor

Figure 3: Relative risks (RRs) and the corresponding $95 \%$ confidence intervals (CIs) for the beverage-specific doseresponse relationship in overall population. The solid line and the long dash line represent the estimated RRs and their 95\% CIs.

A

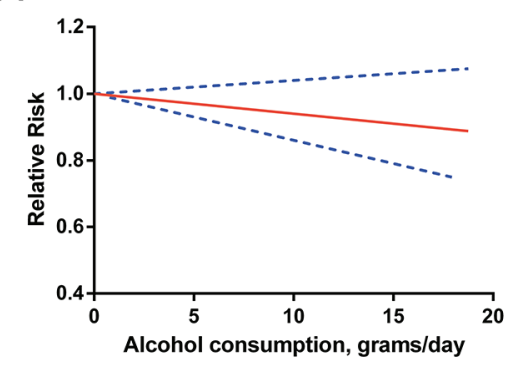

Wine
B

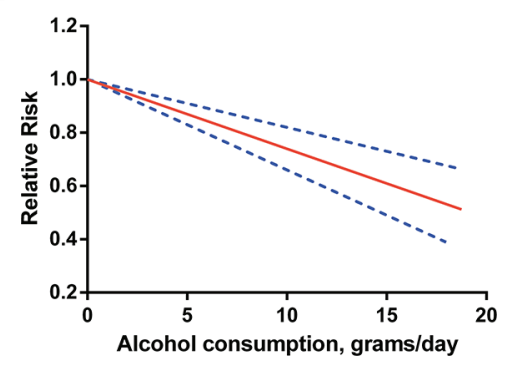

Beer
C

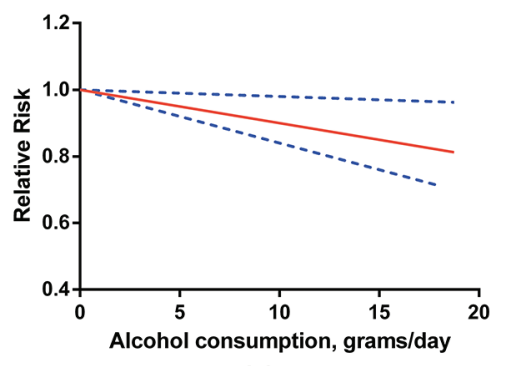

Liquor

Figure 4: Relative risks (RRs) and the corresponding $95 \%$ confidence intervals (CIs) for the beverage-specific doseresponse relationship in males. The solid line and the long dash line represent the estimated RRs and their 95\% CIs.

A

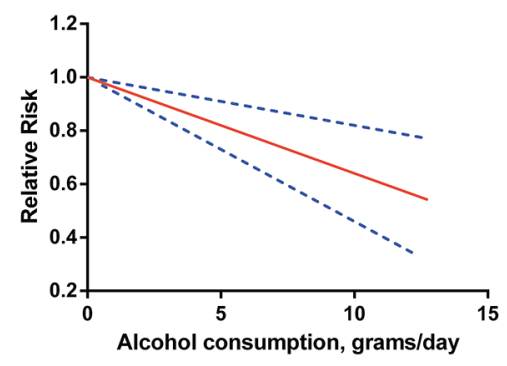

Wine
B

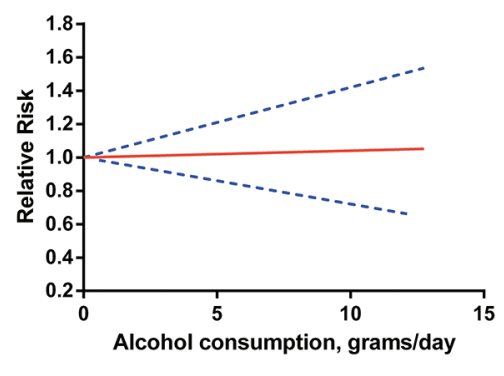

Beer
C

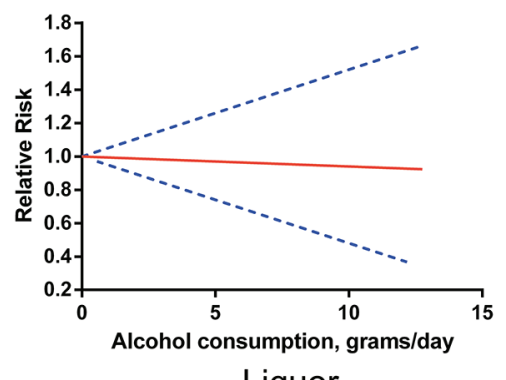

Liquor

Figure 5: Relative risks (RRs) and the corresponding 95\% confidence intervals (CIs) for the beverage-specific doseresponse relationship in females. The solid line and the long dash line represent the estimated RRs and their 95\% CIs.

significant inverse associations were restricted to alcohol from beer and from liquor among males $(\mathrm{RR}=0.87$, 95\% CI $0.83-0.91$ and $\mathrm{RR}=0.95,95 \%$ CI $0.92-0.99$, respectively) (Figure 4) and to alcohol from wine among females $(\mathrm{RR}=0.82,95 \%$ CI $0.73-0.91)$ (Figure 5). There was no evidence of nonlinearity. All $P$ values for nonlinear assessment were $>0.05$.

In dose-response analysis, evidence of heterogeneity across studies was examined by the heterogeneity test. We did not find any significant difference among study-specific slopes in any of the dose-risk curve-fit model (All $P>0.10$ ).

\section{DISCUSSION}

The present meta-analysis summarized the evidence from all available prospective cohort studies and found a significant $25 \%$ decreased risk of RCC for moderate drinking (2-3 drinks/day), compared with non/occasional drinking. A slightly more beneficial effect was observed for females. The dose-response analysis showed that each $5 \mathrm{~g} /$ day increment of alcohol intake corresponded to a $5 \%$ decrease in risk of RCC for males and $9 \%$ for females. In beverage-specific dose-response analysis, 
alcohol intakes from wine, beer, and liquor were each associated with a reduced risk of RCC among the overall population. When beverage-specific associations were further examined separately by gender, statistically significant inverse associations were restricted to alcohol from beer and from liquor among males and to alcohol from wine among females. The findings of our study provide new and more detailed information for the inverse association between alcohol intake and RCC risk.

Several potential biologic mechanisms have been proposed to explain the inverse association between alcohol intake and RCC risk. First, light to moderate alcohol drinking is associated with improved insulin sensitivity $[20,21]$ and protective for type 2 diabetes [22]. Increased risk of RCC has been observed for individuals with diabetes or obesity [23, 24]. Second, alcohol contains antioxidant phenolic compounds, which can reduce oxidative stress and contribute to apoptosis by arresting cell cycle $[25,26]$. Third, alcohol consumption has been inversely associated with the risk of chronic renal failure [27], which is an important risk factor for RCC development [28]. Forth, the diuretic effect of alcohol may also play a role by reducing the time that carcinogenic solutes are in contact with renal epithelial cells [14] and controlling hypertension [29], which is also a well-known RCC risk factor [2]. However, the association of total fluid intake with RCC risk has not been established [29, 30].

There are risk differences between the genders for total alcohol intake and for certain types of alcoholic beverage. Statistically significant inverse associations were restricted to alcohol from wine among females and to alcohol from beer and from liquor among males, which might be due to the discrepancy in the genetics, total body water, metabolic characteristics of alcohol, or other unknown factors $[31,32]$. The most apparent relationships were observed for beer among males and for wine among females in this study, which were consist with the results of Lee et al.' pooled analysis [14] and another large prospective cohort study conducted by Lew et al. [19]. This may be partially because beer was the most popular beverage among males, while females mostly preferred wine [33]. Nevertheless, the exact mechanism underling the gender-specific and beverage-specific differences remains elusive and further investigation is warranted.

Two well-done systematic reviews performed by Bellocco et al. [9] and Song et al. [10] in 2012 has verified the inverse association of alcohol drinking with RCC risk. But their conclusions were drawn mainly based on case-control studies. Moreover, the results of recently published prospective cohort studies remain controversial [11-13]. Hence, an updated meta-analysis of prospective studies is needed and will provide more robust evidence as prospective studies can minimize selection biases and recall biases. In the present meta-analysis, despite of the limited number of included publications, the total sample size is large (more than 5,500 RCC cases). Furthermore,
Lee et al.'s article [14] is consist of 12 cohort studies, thus a total of 19 independent cohort studies were actually analyzed in this meta-analysis. Apart from an inverse, nonlinear association between total alcohol intake and RCC risk that has been suggested in previous meta-analyses, our study uncovers several novel and interesting findings on gender-specific and beverage-specific differences, which will provide some advice for people on choosing the appropriate drink (beer, wine, or liquor).

There are also great deals of research that have investigated the association of alcohol drinking with other site-specific cancer risk. According to a recent comprehensive review [34], RRs for heavy drinking compared with non/occasional drinking were 5.13 for oral and pharyngeal, 4.95 for esophageal, 2.65 for laryngeal, 2.64 for gallbladder, 2.07 for liver, 1.61 for breast, and 1.44 for colorectal cancer. Although our study found no association between heavy alcohol drinking and RCC risk, a large cohort study of alcohol abusers indicated a significantly elevated occurrence of renal cancer in this population [35]. In addition, although controversy still exists, emerging evidence has indicated that moderate drinkers tend to have better health and live longer than those who are either abstainers or heavy drinkers [36]. Moderate drinking has shown benefits on type 2 diabetes [22], heart health [37], strokes [38], Alzheimer's Disease [39], and so on. Our study offers some evidence to support the recommendation of moderate drinking, especially beer in males and wine in females. Klatsky et al.' study [40] assessed the role of alcoholic beverage choice in coronary risk and they also suggested that beer in males and wine in females had the strongest protection.

Our study has several strengths. First, all included studies were prospective cohort studies with a total of 5,503 RCC cases. Prospective studies have the advantage of being less subject to selection and recall bias than casecontrol studies. Second, the combined use of categorical and dose-response analyses provided a comprehensive assessment of the association between alcohol drinking and RCC risk. Third, we were able to evaluate the associations for males and females separately and for each alcoholic beverage.

Several limitations should also be discussed. First, significant heterogeneity was detected in categorical analysis. Therefore, these combined estimates should be treated with caution, although random-effects models were used to take heterogeneity into account. But no obvious heterogeneity was observed for dose-response analysis. Second, only published studies were included in our meta-analysis. Even if Begg's test and Egger' test did not suggest any evidence of publication bias, some inevitable publication bias may exist as studies with null results tend not to be published. Third, a meta-analysis is unable to solve problems with confounding factors that could be inherent in the included studies. The possibility of residual or unmeasured confounding cannot 
be excluded. Nevertheless, in majority of the original studies, main confounders (e.g., age, race, smoking, BMI, hypertension, and physical activity) were adjusted, or at least mostly. Finally, the number of studies included in the meta-analysis was limited. Because of this, more future prospective studies are warranted to confirm the conclusions in this study.

\section{CONCLUSION}

This updated dose-response meta-analysis of prospective cohort studies suggests there exist genderspecific and beverage-specific differences in the association between alcohol intake and RCC risk. Statistically significant inverse associations were restricted to alcohol from beer and from liquor among males and to alcohol from wine among females. Future research is needed to investigate the potential mechanisms underlying these associations.

\section{MATERIALS AND METHODS}

\section{Literature search}

This systematic review and meta-analysis was performed according to meta-analysis of observation studies in epidemiology (MOOSE) guidelines [41]. A systematic literature search in PubMed and EMBASE databases from their inception to February 21, 2015 was conducted by two reviewers (XX and YZ), who understood about basic structure and functions of bibliographic and specialized databases, as well as the methodological and technical issues associated with searching [42]. We used the following search string in PubMed: ("kidney cancer" OR "kidney neoplasm" OR "kidney carcinoma" OR "renal carcinoma” OR "renal cancer" OR "renal cell cancer" OR "renal cell carcinoma") AND (alcohol OR alcohols OR alcoholic OR ethanol OR wine OR beer OR liquor) AND (cohort OR prospective OR "nested casecontrol"). A similar strategy was used in EMBASE search. No language restriction was applied. We also reviewed the cited references from retrieved articles and reviews for additional relevant studies. In addition, we searched the grey literature extensively to check for publication bias. If relevant studies did not provide sufficient data for metaanalysis, we contacted authors to request missing data.

\section{Eligibility criteria}

Articles included in this meta-analysis had to meet the following criteria: (i) cohort or nested case-control study conducted on the general population; (ii) one of the exposures was alcohol drinking; (iii) one of the outcomes was RCC risk; and (iv) studies reported risk estimates with their 95\% confidence intervals (CIs), or data to calculate them. Studies on special populations (e.g., cohorts of alcoholics) $[35,43]$ were not included. If multiple publications from the same or overlapping population were available, the most informative one was included. In particular, we included a pooled analysis of 12 cohort studies [14], rather than separate publications, since seven of these cohorts had not previously reported on this association.

\section{Data extraction and quality assessment}

Two authors independently extracted the following data in a standard format: first author's surname, publication year, country, gender, age, duration of followup, the method of exposure assessment, the number of cases, sample size (persons or person-years), covariates adjusted in the analysis, alcohol exposure levels and corresponding estimates with $95 \%$ CIs. For studies that reported several multivariable-adjusted relative risks (RRs), we extracted the RR estimate that was maximally adjusted for potential covariates to reduce the risk of possible residual confounding.

Two reviewers independently completed the quality assessment using the Newcastle-Ottawa Quality Assessment Scale (http://www.ohri.ca/programs/clinical_ epidemiology/oxford.asp). This scale is an eight-item instrument used to assess the selection of study population, study comparability, and ascertainment of the outcome. The total score ranges from zero to nine, and higher scores indicate better methodological quality. Discrepancies were resolved by consensus and discussion.

\section{Statistical methods}

We converted the amount of alcohol intake into a uniform measurement of grams ( $\mathrm{g}$ ) of ethanol per day by using the following equivalencies: $1 \mathrm{ml}$ of alcohol as $0.8 \mathrm{~g}$ of ethanol, one drink as $12.5 \mathrm{~g}$, and 1 ounce as $28 \mathrm{~g}$ [44, 45], if not otherwise specified in the original article. When a range of alcohol consumption was provided, the median or mean value was regarded as the corresponding exposure dose. If the median or mean value was not reported, we used the midpoint of each category. For upper, open-ended exposure categories, the exposure dose was defined by the lower bound added to the three-quarters of the adjacent previous category [46]. The lowest categories of exposure (i.e., non/occasional drinking) were treated as the reference group. Alcohol drinking were classified into three levels as light, moderate, and heavy drinking, which were defined as ethanol intake of $<12.5 \mathrm{~g} /$ day $(<1 \mathrm{drink} /$ day $), 12.5-37.5$ g/day (2-3 drinks/day), and $>37.5 \mathrm{~g} /$ day ( $>3$ drinks/day), respectively. When multiple exposure categories lay in one of these levels, we pooled the corresponding estimates using the method proposed by Hamling et al. [47], thus taking into account their correlation. In the Million Women Study [15], we back calculate conventional 95\% CIs from a set of RRs reported with 95\% floated CIs [48].

We calculated pooled RRs using random effects model [49] that accounts for both within- and between- 
study heterogeneity, which was also assessed by the Q statistic (significance level at $P<0.10$ ) and the $I^{2}$ score [50]. To evaluate the robustness of the pooled estimates, sensitivity analysis was performed by removing each study in turn. In order to investigate possible sources of heterogeneity among studies, we also conducted subgroups analyses by the available characteristics of studies and participants.

Dose-response meta-analysis was performed by the method described by Greenland et al. [51] and Orsini et al [52]. Only studies that considered at least 3 quantitative categories and provided the number of cases and personyears in each category were included. If studies only provided the overall person-years, we estimated the distribution of person-years using the method proposed by Aune et al. [53]. And if the overall person-years were also not reported, it was approximated from follow-up duration and number of individuals [54]. We examined a potential nonlinear dose-response relationship between alcohol intake and RCC risk using restricted cubic splines with three knots at the 25th, 50th, and 75th percentiles of the distribution. A $P$ value for nonlinearity was calculated by testing the null hypothesis that the coefficient of the second spline was equal to zero [55].

Publication bias was evaluated by Begg's test (rank correlation method) [56] and Egger's test (linear regression method) [57]. All statistical analyses were performed with STATA 11.0 (StataCorp, College Station, TX) and a two-sided $P<0.05$ was considered significant.

\section{ACKNOWLEDGMENTS}

This study was supported by grants from the National Key Clinical Specialty Construction Project of China, Key Medical Disciplines of Zhejiang Province, Health Sector Scientific Research Special Project (201002010), Combination of Traditional Chinese and Western Medicine Key Disciplines of Zhejiang Province (2012-XK-A23), Zhejiang Province Key Project of Science and Technology (2014C04008-2), National Natural Science Foundation of China (81472375, 81372773, 81201767), Scientific Research Foundation of the Ministry of Public Health of China (WKJ2012-2-009).

\section{CONFLICTS OF INTEREST}

The authors declare that there are no conflicts of interest.

\section{REFERENCES}

1. Ferlay J, Shin HR, Bray F, Forman D, Mathers C, Parkin DM. Estimates of worldwide burden of cancer in 2008. GLOBOCAN 2008. Int J Cancer. 2010; 127:2893-2917.
2. Chow WH, Dong LM, Devesa SS. Epidemiology and risk factors for kidney cancer. Nat Rev Urol. 2010; 7:245-257.

3. Weikert S, Ljungberg B. Contemporary epidemiology of renal cell carcinoma: perspectives of primary prevention. World J Urol. 2010; 28:247-252.

4. Siegel RL, Miller KD, Jemal A. Cancer statistics, 2015. CA Cancer J Clin. 2015 Jan-Feb; 65:5-29.

5. Jonasch E, Gao J, Rathmell WK. Renal cell carcinoma. BMJ. 2014; 349:g4797.

6. Chow WH, Devesa SS, Warren JL, Fraumeni JF Jr. Rising incidence of renal cell cancer in the United States. JAMA. 1999; 281:1628-1631.

7. Lightfoot N, Conlon M, Kreiger N, Bissett R, Desai M, Warde P, Prichard HM. Impact of noninvasive imaging on increased incidental detection of renal cell carcinoma. Eur Urol. 2000; 37:521-527.

8. Ljungberg B, Campbell SC, Choi HY, Jacqmin D, Lee JE, Weikert S, Kiemeney LA. The epidemiology of renal cell carcinoma. Eur Urol. 2011; 60:615-621.

9. Bellocco R, Pasquali E, Rota M, Bagnardi V, Tramacere I, Scotti L, Pelucchi C, Boffetta P, Corrao G, La Vecchia C. Alcohol drinking and risk of renal cell carcinoma: results of a meta-analysis. Ann Oncol. 2012; 23:2235-2244.

10. Song DY, Song S, Song Y, Lee JE. Alcohol intake and renal cell cancer risk: a meta-analysis. Br J Cancer. 2012; 106:1881-1890.

11. Macleod LC, Hotaling JM, Wright JL, Davenport MT, Gore JL, Harper J, White E. Risk factors for renal cell carcinoma in the VITAL study. J Urol. 2013; 190:1657-1661.

12. Karami S, Daugherty SE, Purdue MP. A prospective study of alcohol consumption and renal cell carcinoma risk. Int $\mathrm{J}$ Cancer. 2015; 137:238-42 .

13. Washio M, Mori M, Mikami K, Miki T, Watanabe Y, Nakao M, Kubo T, Suzuki K, Ozasa K, Wakai K, Tamakoshi A. Cigarette smoking and other risk factors for kidney cancer death in a Japanese population: Japan Collaborative Cohort Study for evaluation of cancer risk (JACC study). Asian Pac J Cancer Prev. 2014; $14: 6523-6528$.

14. Lee JE, Hunter DJ, Spiegelman D, Adami HO, Albanes D, Bernstein L, van den Brandt PA, Buring JE, Cho E, Folsom AR, Freudenheim JL, Giovannucci E, Graham S, et al. Alcohol intake and renal cell cancer in a pooled analysis of 12 prospective studies. J Natl Cancer Inst. 2007; 99:801-810.

15. Allen NE, Beral V, Casabonne D, Kan SW, Reeves GK, Brown A, Green J. Moderate alcohol intake and cancer incidence in women. J Natl Cancer Inst. 2009; 101:296-305.

16. Ozasa K. Alcohol use and mortality in the Japan Collaborative Cohort Study for Evaluation of Cancer (JACC). Asian Pac J Cancer Prev. 2007; :81-88.

17. Setiawan VW, Stram DO, Nomura AM, Kolonel LN, Henderson BE. Risk factors for renal cell cancer: the multiethnic cohort. Am J Epidemiol. 2007; 166:932-940. 
18. Kim MK, Ko MJ, Han JT. Alcohol consumption and mortality from all-cause and cancers among 1.34 million Koreans: the results from the Korea national health insurance corporation's health examinee cohort in 2000. Cancer Causes Control. 2010; 21:2295-2302.

19. Lew JQ, Chow WH, Hollenbeck AR, Schatzkin A, Park Y. Alcohol consumption and risk of renal cell cancer: the NIH-AARP diet and health study. Br J Cancer. 2011; 104:537-541.

20. Davies MJ, Baer DJ, Judd JT, Brown ED, Campbell WS, Taylor PR. Effects of moderate alcohol intake on fasting insulin and glucose concentrations and insulin sensitivity in postmenopausal women: a randomized controlled trial. JAMA. 2002; 287:2559-2562.

21. Facchini F, Chen YD, Reaven GM. Light-to-moderate alcohol intake is associated with enhanced insulin sensitivity. Diabetes Care. 1994; 17:115-119.

22. Baliunas DO, Taylor BJ, Irving H, Roerecke M, Patra J, Mohapatra S, Rehm J. Alcohol as a risk factor for type 2 diabetes: A systematic review and meta-analysis. Diabetes Care. 2009; 32:2123-2132.

23. Wang F, Xu Y. Body mass index and risk of renal cell cancer: a dose-response meta-analysis of published cohort studies. Int J Cancer. 2014; 135:1673-1686.

24. Larsson SC, Wolk A. Diabetes mellitus and incidence of kidney cancer: a meta-analysis of cohort studies. Diabetologia. 2011; 54:1013-1018.

25. Huang WY, Cai YZ, Zhang Y. Natural phenolic compounds from medicinal herbs and dietary plants: potential use for cancer prevention. Nutr Cancer. 2010; 62:1-20.

26. Halliwell B. Free radicals, antioxidants, and human disease: curiosity, cause, or consequence?. Lancet. 1994; 344:721-724.

27. Koning SH, Gansevoort RT, Mukamal KJ, Rimm EB, Bakker SJ, Joosten MM. Alcohol consumption is inversely associated with the risk of developing chronic kidney disease. Kidney Int. 2015.

28. Hofmann JN, Schwartz K, Chow WH, Ruterbusch JJ, Shuch BM, Karami S, Rothman N, Wacholder S, Graubard BI, Colt JS, Purdue MP. The association between chronic renal failure and renal cell carcinoma may differ between black and white Americans. Cancer Causes Control. 2013; 24:167-174.

29. Lee JE, Giovannucci E, Smith-Warner SA, Spiegelman D, Willett WC, Curhan GC. Total fluid intake and use of individual beverages and risk of renal cell cancer in two large cohorts. Cancer Epidemiol Biomarkers Prev. 2006; 15:1204-1211.

30. Allen NE, Balkwill A, Beral V, Green J, Reeves G. Fluid intake and incidence of renal cell carcinoma in UK women. Br J Cancer. 2011; 104:1487-1492.

31. Nolen-Hoeksema S, Hilt L. Possible contributors to the gender differences in alcohol use and problems. J Gen Psychol. 2006; 133:357-374.
32. Bradley KA, Badrinath S, Bush K, Boyd-Wickizer J, Anawalt B. Medical risks for women who drink alcohol. J Gen Intern Med. 1998; 13:627-639.

33. Geels LM, Vink JM, van Beek JH, Bartels M, Willemsen G, Boomsma DI. Increases in alcohol consumption in women and elderly groups: evidence from an epidemiological study. BMC Public Health. 2013; 13:207.

34. Bagnardi V, Rota M, Botteri E, Tramacere I, Islami F, Fedirko V, Scotti L, Jenab M, Turati F, Pasquali E, Pelucchi C, Galeone C, Bellocco R, et al. Alcohol consumption and site-specific cancer risk: a comprehensive doseresponse meta-analysis. Br J Cancer. 2014; .

35. Thygesen LC, Mikkelsen P, Andersen TV, Tonnesen H, Juel K, Becker U, Gronbaek M. Cancer incidence among patients with alcohol use disorders-long-term follow-up. Alcohol Alcohol. 2009; 44:387-391.

36. Pedersen JO, Heitmann BL, Schnohr P, Gronbaek M. The combined influence of leisure-time physical activity and weekly alcohol intake on fatal ischaemic heart disease and all-cause mortality. Eur Heart J. 2008; 29:204-212.

37. Katsiki N, Tziomalos K, Mikhailidis DP. Alcohol and the cardiovascular system: a double-edged sword. Curr Pharm Des. 2014; 20:6276-6288.

38. Patra J, Taylor B, Irving H, Roerecke M, Baliunas D, Mohapatra S, Rehm J. Alcohol consumption and the risk of morbidity and mortality for different stroke types-a systematic review and meta-analysis. BMC Public Health. 2010; 10:258.

39. Anstey KJ, Mack HA, Cherbuin N. Alcohol consumption as a risk factor for dementia and cognitive decline: metaanalysis of prospective studies. Am J Geriatr Psychiatry. 2009; 17:542-555.

40. Klatsky AL, Armstrong MA, Friedman GD. Red wine, white wine, liquor, beer, and risk for coronary artery disease hospitalization. Am J Cardiol. 1997; 80:416-420.

41. Stroup DF, Berlin JA, Morton SC, Olkin I, Williamson GD, Rennie D, Moher D, Becker BJ, Sipe TA, Thacker SB. Meta-analysis of observational studies in epidemiology: a proposal for reporting. Meta-analysis Of Observational Studies in Epidemiology (MOOSE) group. JAMA. 2000; 283:2008-2012.

42. McGowan J, Sampson M. Systematic reviews need systematic searchers. J Med Libr Assoc. 2005; 93:74-80.

43. Tonnesen H, Moller H, Andersen JR, Jensen E, Juel K. Cancer morbidity in alcohol abusers. Br J Cancer. 1994; 69:327-332.

44. Bagnardi V, Rota M, Botteri E, Tramacere I, Islami F, Fedirko V, Scotti L, Jenab M, Turati F, Pasquali E, Pelucchi $\mathrm{C}$, Galeone C, Bellocco R, et al. Alcohol consumption and site-specific cancer risk: a comprehensive dose-response meta-analysis. Br J Cancer. 2015; 112:580-593.

45. Jin M, Cai S, Guo J, Zhu Y, Li M, Yu Y, Zhang S, Chen K. Alcohol drinking and all cancer mortality: a meta-analysis. Ann Oncol. 2013; 24:807-816. 
46. Patra J, Bakker R, Irving H, Jaddoe VW, Malini S, Rehm J. Dose-response relationship between alcohol consumption before and during pregnancy and the risks of low birthweight, preterm birth and small for gestational age (SGA)-a systematic review and meta-analyses. BJOG. 2011; 118:1411-1421.

47. Hamling J, Lee P, Weitkunat R, Ambuhl M. Facilitating meta-analyses by deriving relative effect and precision estimates for alternative comparisons from a set of estimates presented by exposure level or disease category. Stat Med. 2008; 27:954-970.

48. Orsini N. From floated to conventional confidence intervals for the relative risks based on published dose-response data. Comput Methods Programs Biomed. 2010; 98:90-93.

49. DerSimonian R, Laird N. Meta-analysis in clinical trials. Control Clin Trials. 1986; 7:177-188.

50. Higgins JP, Thompson SG. Quantifying heterogeneity in a meta-analysis. Stat Med. 2002; 21:1539-1558.

51. Greenland S, Longnecker MP. Methods for trend estimation from summarized dose-response data, with applications to meta-analysis. Am J Epidemiol. 1992; 135:1301-1309.
52. Orsini N, Li R, Wolk A, Khudyakov P, Spiegelman D. Meta-analysis for linear and nonlinear dose-response relations: examples, an evaluation of approximations, and software. Am J Epidemiol. 2012; 175:66-73.

53. Aune D, Greenwood DC, Chan DS, Vieira R, Vieira AR, Navarro Rosenblatt DA, Cade JE, Burley VJ, Norat T. Body mass index, abdominal fatness and pancreatic cancer risk: a systematic review and non-linear dose-response metaanalysis of prospective studies. Ann Oncol. 2012; 23:843-852.

54. Moskal A, Norat T, Ferrari P, Riboli E. Alcohol intake and colorectal cancer risk: a dose-response meta-analysis of published cohort studies. Int J Cancer. 2007; 120:664-671.

55. Desquilbet L, Mariotti F. Dose-response analyses using restricted cubic spline functions in public health research. Stat Med. 2010; 29:1037-1057.

56. Begg CB, Mazumdar M. Operating characteristics of a rank correlation test for publication bias. Biometrics. 1994; 50:1088-1101.

57. Egger M, Davey Smith G, Schneider M, Minder C. Bias in meta-analysis detected by a simple, graphical test. BMJ. 1997; 315:629-634. 